І.А. Дмитренко ${ }^{1}$ О.К. Толстанов ${ }^{2}$

1/вано-Франківський національний медичний університет

${ }^{2}$ Національна медична академія післядипломної освіти імені П.Л. Шупика, Київ

\title{
Стоматологічне здоров'я населення громади: проблеми та можливості покращення (на прикладі Івано-Франківської області)
}

Мета: провести теоретичний аналіз даних про стан здоров'я порожнини рота населення Івано-Франківської області за період 2008-2018 рр. та можливості ресурсного забезпечення стоматологічної допомоги у регіоні. Об'єкт дослідження: здоров'я порожнини рота населення Івано-Франківської області. Предмет дослідження: хвороби зубів, слизової оболонки та онкологічна патологія порожнини рота, ресурсне забезпечення стоматологічної служби. Методи дослідження: системного підходу, системного аналізу, узагальнення, медико-статистичний. Результати. Встановлено, що захворюваність на карієс зубів населення області залишається стабільно високою, а питома вага ускладненого карієсу зросла з 21,6 до 25,0\% й перевищила показники по Україні. Поширеність карієсу зубів серед дитячого населення коливається в межах 71,4-90,6\% залежно від віку і місця проживання. Частота генералізованого пародонтиту серед населення становить 7,0-18,0\%, пародонтозу - 4,9\%. В області зростає первинна захворюваність на рак ротової порожнини, у половині випадків - за рахунок задавнених стадій. У регіоні достатній кадровий та інфраструктурний ресурс для задоволення потреб населення у стоматологічній допомозі, однак погіршення здоров'я порожнини рота свідчить про обмеженість профілактичних технологій. Висновки. Отримані дані можна врахувати при розробці регіональної програми профілактики і подолання хвороб порожнини рота населення Івано-Франківської області.

Ключові слова: здоров'я порожнини рота, карієс, пародонтоз, пародонтит, рак, населення, ресурсне забезпечення.

\section{Вступ}

Оцінка здоров'я місцевих громад з метою визначення потреб населення у профілактичних та лікувально-діагностичних програмах, виявлення груп ризику й результатів моніторингу прогресу у вирішенні завдань охорони здоров'я є складником однієї з десяти основних оперативних функцій громадського здоров'я (Слабкий Г.О. та співавт., 2017). Внесок здоров'я порожнини рота у загальне здоров'я місцевих громад важко переоцінити, оскільки, за даними глобального дослідження тягаря хвороб 2016 р., захворювання ротової порожнини діагностують у половини населення світу (GBD 2016 Disease and Injury Incidence and Prevalence Collaborators, 2017).

На думку експертів і дослідників, здоров'я порожнини рота один із основних показників загального здоров'я, благополуччя та якості життя (BO3, 2018; Fisher J. et al., 2018). Зважаючи на значну задавненість, покращення здоров'я порожнини рота може зробити значний позитивний внесок у поліпшення останніх.

До хвороб порожнини рота населення України прикута увага науковців, організаторів охорони здоров'я, лікарів (Кононова О.В., 2014; Шварцнау Е.Г., Ковач И.В., 2015; Бойцанюк С.І. та співавт., 2016; Яковенко Л.М. та співавт., 2016). Оскільки ця проблема у нашій країні, як і в усьому світі, залишається невирішеною, її актуальність не викликає сумнівів, що потребує нових наукових розробок. Актуальність проблеми значно посилюється розвитком адміністративно-територіальної реформи в Україні, коли піклування про здоров'я громади покладається значною мірою на органи місцевого самоврядування та власне на саму громаду.

Мета - провести теоретичний аналіз даних, що характеризують динаміку стану здоров'я порожнини рота населення Івано-Франківської області за період 2008-2018рр., та можливості ресурсного забезпечення стоматологічної допомоги у цьому регіоні.

\section{Об'єкт і методи дослідження}

Об'єкт дослідження - здоров'я порожнини рота населення Івано-Франківської області за період 2008-2018 рр., предмет дослідження - хвороби зубів, слизової оболонки рота, онкологічні хвороби ротової порожнини, ресурсне забезпечення стоматологічної служби.

Як матеріали використані статистичні дані Центру медичної статистики Міністерства охорони здоров'я (МО3) України за період 2008-2018 рр. на тему дослідження (64 од.), джерела наукової літератури (17 од.). Застосовували методи системного підходу і системного аналізу, узагальнення, медико-статистичний.

\section{Результати та їх обговорення}

Системний аналіз доступних наукових публікацій та статистичних даних свідчить, що епідеміологічні дослідження захворювань порожнини рота в Україні, зокрема в Івано-Франківській області, носять фрагментарний характер, а дані вітчизняної статистики не відповідають за критеріями і структурою європейським індикаторам. Разом з тим навіть окремі повідомлення дозволяють зробити попередні висновки, що ця група патологій вимагає постійної уваги та активного втручання з боку лікарів, організаторів охорони здоров'я, пацієнтів, громади, органів місцевого самоврядування і $€$ актуальною медико-соціальною проблемою.

Найбільшу тривогу викликає ураженість зубів мешканців ІваноФранківської області карієсом. Так, за даними галузевої статистики Центру медичної статистики МОЗ України за період 20082018 рр., утримується значна питома вага пролікованих зубів з приводу карієсу щодо усіх стоматологічних відвідувань у закладах охорони здоров'я області, які належать до системи МО3 України: 74,3\% у 2008 р., 70,6\% - у 2018 р. при відповідних показниках по Україні 56, 9 та 55,7\%. Тобто захворюваність на карієс в області залишається стабільно високою. Питома вага ускладненого карієсу до усіх пролікованих зубів з приводу карієсу більша по регіону, ніж в Україні, й постійно зростає: з 21,6\% у 2008 р. до $25,0 \%$ - у 2018 р. при показниках в цілому по галузі 22,1 та 24,6\% відповідно.

Карієс зубів найбільше вражає дитяче населення Івано-Франківської області. Дослідниками (Октисюк Ю.В., Рожко М.М., 2013; Попович З.Б. та співавт., 2014) поширеність цієї хвороби серед 
зазначеного контингенту оцінюється як масова і розглядається диференційовано - залежно від місця проживання. Доведено, що у гірській зоні поширеність карієсу серед дітей в 1,04 раза, а в передгірській - в 1,02 раза вища, ніж у рівнинній місцевості $(p<0,05)$. У дітей віком 12 років - жителів Калуського району поширеність карієсу становить $71,4 \%$, інтенсивність ураження 2,1 зуба, 15 років - 89,8\% і 3,4 зуба відповідно. Близькі за значеннями показники у Галицькому районі: поширеність карієсу серед дітей віком 12 років - 73,1\%, інтенсивність ураження 2,2 зуба, 15 років - 90,6\% і 3,6 зуба відповідно. Водночас у Городенківському районі поширеність карієсу у дітей віком 12 років становить $38,6 \%$, інтенсивність ураження - 1,7 зуба, 15 років $69,2 \%$ і 1,9 зуба відповідно.

Відмінності зазначені за результатами дослідження поширеності карієсу і у студентської молоді (Олексин Х.З., Рожко М.М., 2018а; б). Найчастіше карієс виявляли у студентів, які проживали у Надвірнянському й Верховинському районах Івано-Франківської області, у яких частота ураження хронічним середнім карієсом досягала $24,1 \pm 5,82 \%$, зокрема ураження оклюзійних поверхонь жувальних

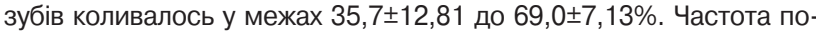
ширення гострого карієсу перших великих кутніх зубів становила $22,7 \pm 2,42 \%$, хронічного - 30,7士2,66\%. Поширеність хронічного

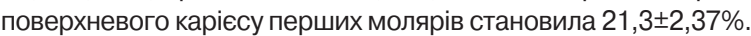

Ще одна проблема жителів Івано-Франківській області - захворювання пародонта. За результатами досліджень (Малий Д.Ю., Антоненко М.Ю., 2013), частота генералізованого пародонтиту у мешканців гірських районів становить 18\%, передгірських - 7\%, рівнинних - 10\%. Пародонтоз виявлено у 4,9\% жителів рівнинних і передгірських районів. Зокрема серед підлітків області з хвороб пародонта виявлено кровоточивість у $32,4 \pm 3,8 \%$, зубний камінь у 59,8 5,3\% обстежених (Казакова Р.В. та співавт., 2013).

Захворюваність слизової оболонки порожнини рота на 10 тис. населення, за даними галузевої статистичної звітності, зросла впродовж 2008-2018 рр. по області з 68,2 до 81,6, тоді як по Україні - помітно знизилася: з 101,5 до 84,2 на 10 тис. населення. Найбільше зростання припадало на доросле населення області з 52,4 до 69,7 на 10 тис. населення, при цьому по Україні відповідні показники знизилися з 89,2 до 75,1 на 10 тис. населення. Аналогічні тенденції змін показника простежували серед дитячого населення: по області - зростання з 125,5 до 128,5, по Україні - зниження з 157,3 до 125,4 на 10 тис. населення.

Важливою медико-соціальною проблемою в Івано-Франківській області, як і загалом в Україні, слід вважати злоякісні новоутворення губи та порожнини рота. У період 2008-2018 рр. відзначали зменшення в популяції регіону хворих на злоякісні новоутворення губи з 497 до 323 осіб, що у показниках поширеності становило 36,0 та 23,5 на 100 тис. населення відповідно. Загальноукраїнські показники становили 50,9 та 28,4 на 100 тис. населення відповідно. Первинна захворюваність також знизилась як по області - з 2,2 до 1,5, так і по всій Україні - з 2,5 до 1,3 на 100 тис. населення.

Водночас більш несприятливою виявилась епідемічна ситуація по захворюваності назлоякісні новоутворення порожнини рота. Контингент хворих на кінець 2008 р. в області становив 184 особи, а на кінець 2018 р. - вже 246 осіб, що в показниках поширеності 13,3 та 17,9 на 100 тис. населення області відповідно, при галузевому показникові 19,8 та 23,3 на 100 тис. населення України. Відзначали також зростання первинної захворюваності: більш високими темпами по області - з 3,9 до 5,2, ніж по Україні - 3 4,9 до 5,0 на 100 тис. населення.

За даними О.З. Децик, І.В. Рудко (2017), в Івано-Франківській області спостерігається загрозлива епідемічна ситуація щодо раку порожнини рота внаслідок зростання первинної захворюваності, зокрема у половині випадків - за рахунок задавнених стадій. Понад 40,0\% вперше виявлених випадків завершуються летальним кінцем упродовж року. Частка випадків, виявлених при профілактичних оглядах, залишається незначною (28,8\% у 2016 р.). Близько 80,0\% випадків раку порожнини рота вперше виявляють на пізніх стадіях.

Зокрема у місті Івано-Франківську у 2019 р. виявлено 283 пацієнти з раком візуальної локалізації, з них - 61 (21,5\%) у III-IV стадії захворювання. Найбільша частка задавненості, а саме - усі випадки (5 од.) - припадали на рак порожнини рота, що поясню- ється експертами пізнім зверненням пацієнтів та відсутністю щорічних онкологічних профілактичних оглядів, низьким рівнем онкологічної настороженості лікарів-стоматологів та лікарів загальної практики - сімейної медицини, терапевтів (Управління охороною здоров'я Івано-Франківської міської ради, 2020).

Ресурсну базу стоматологічної допомоги Івано-Франківської області, згідно з результатами аналізу статистичних даних Центру медичної статистики МОЗ України, можна оцінити як задовільну. Так, за період дослідження (2008-2018рр.) в області збереглася мережа самостійних стоматологічних поліклінік у кількості 7 од., при зменшенні кількості стоматологічних відділень (кабінетів) з 186 до 104 од. в рамках реформування регіональної сфери охорони здоров'я.

Забезпеченість населення лікарями-стоматологами у закладах охорони здоров'я області системи МОЗ України зросла з 6,21 до 6,67 на 10 тис. населення і була найвищою в Україні після міста Києва (8,24 у 2008 р., 6,85 на 10 тис. населення - у 2018 р.) та Львівської області (7,41 на 10 тис. населення у 2008 р.).

Укомплектованість штатних посад лікарів-стоматологів з урахуванням сумісництва зберігалася високою, перевищувала показники по Україні й становила у 2008 р. 98,18\%, у 2018 р. - 96,0\% (по Україні - 93,31 та 92,43\% відповідно). Укомплектованість штатнихпосад фізичними особами - лікарями в області помітно зросла - 3119,34 до 129,35\%, тоді як в Україні - з 99,01 до 106,18\%.

Значно збільшилася за період дослідження частка атестованих лікарів-стоматологів в області - 3 70,8\% у 2008 р. до 76,3\% у 2018 р., тоді як в Україні - з 73,3 до 73,7\% відповідно.

Ліжковий фонд стаціонарів області для лікування стоматологічних хворих дорослих не змінився за період дослідження і становив 0,29 на 10 тис. населення, тоді як по Україні - скоротився з 0,32 до 0,28 на 10 тис. населення. Забезпеченість стоматологічними ліжками для дітей в області навіть збільшилась з 0,33 до 0,43 на 10 тис. населення дитячого віку при зниженні відповідного показника по Україні з 0,20 до 0,17 на 10 тис. населення. Забезпеченість дитячими стоматологічними ліжками в ІваноФранківській області є однією з найвищих в Україні, поряд з аналогічним показником 2018 р. по місту Києву (0,55 на 10 тис. населення дитячого віку) та Харківській області $(0,46$ на 10 тис. населення дитячого віку).

Таким чином, при низьких показниках здоров'я порожнини рота населення Івано-Франківської області існує достатній кадровий та інфраструктурний ресурс для його покращення. Водночас зменшення кількості стоматологічних відділень (кабінетів) може свідчити про зниження доступності стоматологічної допомоги для населення області, а несприятлива епідемічна ситуація щодо захворюваності й поширеності карієсу, хвороб слизової оболонки порожнини рота та онкологічної захворюваності свідчить про вплив чинників ризику на стан здоров'я населення, які знаходяться поза межами медичної системи, що потребує подальших наукових досліджень.

\section{Висновки}

1. В Івано-Франківській області стабільно високою впродовж 2008-2018рр. залишалася захворюваність й поширеність карієсу зубів серед населення, особливо у дітей та підлітків.

2. Виявлено тенденції до зростання захворюваності на хвороби пародонта як серед дорослого населення, так і серед дітей та підлітків.

3. Показано, що значної уваги потребує зростання захворюваності на онкологічну патологію порожнини рота населення області як соціально значущої проблеми.

4. 3'ясовано, що Івано-Франківська область володіє достатнім кадровим та інфраструктурним ресурсом для задоволення потреб населення у стоматологічній допомозі. Однак зростання первинної захворюваності на рак та хвороб слизової оболонки порожнини рота, стійке утримання високої поширеності карієсу свідчать про обмеженість профілактичних технологій серед населення області та необхідність подальшого дослідження і врахування факторів ризику захворюваності порожнини рота жителів Прикарпаття, в чому полягають перспективи подальших досліджень.

5. Отримані дані можуть стати складовою інформаційного забезпечення розроблення регіональної програми профілактики та лікування хвороб порожнини рота населення Івано-Франківської області. 


\section{Список використаної літератури}

Бойцанюк С.І., Залізняк М.С., Чорній Н.В. та ін. (2016) Особливості клінічного перебігу захворювань пародонта у хворих із різною супутньою патологією. Клін. стоматол., 2: 14-19.

В03 (2018) Здоровье полости рта (https://www.who.int/ru/news-room/ fact-sheets/detail/oral-health).

Децик 0.3., Рудко І.В. (2017) Аналіз захворюваності та смертності від злоякісних новоутворень губи і ротової порожнини в Україні та Івано-Франківській області за 2007-2016 рр. Україна. Здоров'я нації, 3: 95-100.

Казакова Р.В., Мельник В.С., Білищук М.В. (2013) Порівняльний аналіз показників карієсу зубів і захворювань тканин пародонта у підлітків, які проживають у різних екологічних умовах. Новини стоматол., 1: 78-79.

Кононова О.В. (2014) Сучасний стан лікування карієсу та його ускладнень у населення України. Гігієна населених місць, 64: 336-342.

Малий Д.Ю., Антоненко М.Ю. (2013) Епідеміологія захворювань пародонта: віковий аспект. Укр. наук.-мед. молод. журн., 4: 41-43.

Октисюк Ю.В., Рожко М.М. (2013) Порівняльний аналіз захворюваності на карієс зубів дітей різних клімато-географічних зон Івано-Франківської області у віковому аспекті. Архів клін. мед., 2(19): 51-54.

Олексин Х.З., Рожко М.М. (2018a) Поширеність карієсу перших молярів і його роль у виникненні оклюзійних порушень. Архів клін. мед., 2(24): 20-26.

Олексин Х.З., Рожко М.М. (2018б) Поширеність карієсу у молодих людей, які проживають у регіонах з низьким рівнем фтору. Галиц. лікар. вісн., 25(3): 25-31.

Попович 3.Б., Рожко М.М., Соловей С.І. та ін. (2014) Проблеми довкілля і стан стоматологічного здоров'я дітей Івано-Франківської області. Профілакт. дит. стоматол., 1(10): 6-8.

Слабкий Г.О., Миронюк В.І., Качала Л.О. (2017) Система громадського здоров'я: бачення Всесвітньої організації охорони здоров'я. Основн оперативні функції громадського здоров'я та їх зміст. Україна. Здоров'я нації, 3: $24-31$

Управління охорони здоров'я Івано-Франківської міської ради (2020) Звіт про виконання основних організаційних заходів галузі охорони здоров'я Івано-Франківської міської ради за 2019 рік (http://www.mvk.if.ua/ uploads/files/52261.pdf)

Шварцнау Е.Г., Ковач И.В. (2015) Состояние твердых тканей зубов и пародонта у студентов медицинских учебных заведений. Совр. стоматол., 3 : 9-12.

Яковенко Л.М., Єфименко В.П., Макаревич А.Ю., Ковтун Т.О. (2016) Травми тимчасових і постійних зубів у дітей (діагностичні заходи, лікувальна тактика). Мед. перспект., XXI(4): 106-115.

Fisher J., Selikowitz H-S., Mathur M., Varenne B. (2018) Strengthening oral health for universal health coverage. Lancet, 392 (10151): 899-901. doi: 10.1016/ S0140-6736(18)31707-0.

GBD 2016 Disease and Injury Incidence and Prevalence Collaborators (2017) Global, regional, and national incidence, prevalence, and years lived with disability for 328 diseases and injuries for 195 countries, 1990-2016: a systematic analysis for the Global Burden of Disease Study 2016. Lancet, 390(10100): 1211-1259. doi: 10.1016/S0140-6736(17)32154-2.

\section{Стоматологическое здоровье населения общины: проблемы и возможности улучшения (на примере Ивано-Франковской области)}

\section{И.А. Дмитренко, А.К. Толстанов}

Резюме. Цель: провести теоретический анализ данныхо состоянии здоровья полости рта населения Ивано-Франковской области за период 2008-2018 гг. и возможности ресурсного обеспечения стоматологической помощи в регионе. Объект исследования: здоровье полости рта населения Ивано-Франковской области. Предмет исследования: болезни зубов, слизистой оболочки и онкологиче- ская патология полости рта, ресурсное обеспечение стоматологической службы. Методы исследования: системного подхода, системного анализа, обобщения, медико-статистический. Результаты. Установлено, что заболеваемость кариесом зубов населения области остается стабильно высокой, а удельный вес осложненного кариеса вырос с 21,6 до 25,0\% и превысил показатели по Украине. Распространенность кариеса зубов среди детского населения колеблется в пределах 71,4-90,6\% в зависимости от возраста и места проживания. Частота генерализованного пародонтита среди населения составляет 7,0-18,0\%, пародонтоза - 4,9\%. В области растет первичная заболеваемость раком полости рта, в половине случаев - за счет запущенных стадий. В регионе достаточный кадровый и инфраструктурный ресурс для удовлетворения потребностей населения в стоматологической помощи, однако ухудшение состояния здоровья полости рта свидетельствует об ограниченности профилактических технологий. Выводы. Полученные данные можно учесть при разработке региональной программы профилактики и преодоления болезней полости рта населения Ивано-Франковской области.

Ключевые слова: здоровье полости рта, кариес, пародонтоз, пародонтит, рак, население, ресурсное обеспечение.

\section{Oral health of the community \\ population: problems and opportunities \\ for improvement (on the example of Ivano-Frankivsk region)}

\section{I.A. Dmitrenko, O.K. Tolstanov}

Summary. Purpose: to conduct a theoretical analysis of data on the health of the oral cavity of the population of Ivano-Frankivsk region for 2008-2018 and the possibility of resource provision of dental care in the region. Object of the study: population oral health of Ivano-Frankivsk region. Subject of the study: diseases of the teeth, mucous membranes and oncopathology of the oral cavity, resource provision of the dental service. Research methods: system approach, system analysis, generalization, medical and statistical. Results. It is established that the incidence of dental caries in the population of the region remains consistently high, and the proportion of complicated caries increased from 21.6 to $25.0 \%$ and exceeded the figures for Ukraine. The prevalence of dental caries among children ranges from 71.4 to $90.6 \%$ depending on age and place of residence. The frequency of generalized periodontitis among the population is $7.0-18.0 \%$, and periodontitis $-4.9 \%$. The primary incidence of oral cancer is increasing in the region, in particular in half of the cases - due to neglected stages. There are sufficient human and infrastructural resources to meet the needs of the population in dental care in the region, but the deterioration of oral health indicates the limited preventive technologies. Conclusions. the obtained data can be taken into account when developing a regional program for prevention and overcoming of diseases of the oral cavity of the population of Ivano-Frankivsk region.

Key words: oral health, caries, periodontitis, cancer, population, resource provision.

\section{Адреса для листування:}

Дмитренко Ігор Анатолійович

76018, Івано-Франківськ, вул. Галицька, 2

Івано-Франківський національний медичний університет,

кафедра ортопедичної стоматології

E-mail: altmed.igor.@gmail.com 